\title{
TTR
}

Traduction, terminologie, re?daction

\section{Translation Pedagogy: Strategies for Improving Dictionary Use}

\section{Roda P. Roberts}

Volume 5, numéro 1, 1er semestre 1992

La pédagogie de la traduction : questions actuelles (1) et Miscellanées traductologiques

URI : https://id.erudit.org/iderudit/037106ar

DOI : https://doi.org/10.7202/037106ar

Aller au sommaire du numéro

Éditeur(s)

Association canadienne de traductologie

ISSN

0835-8443 (imprimé)

1708-2188 (numérique)

Découvrir la revue

Citer cet article

Roberts, R. P. (1992). Translation Pedagogy: Strategies for Improving Dictionary Use. TTR, 5(1), 49-76. https://doi.org/10.7202/037106ar d'utilisation que vous pouvez consulter en ligne.

https://apropos.erudit.org/fr/usagers/politique-dutilisation/ 


\title{
Translation Pedagogy: Strategies for Improving Dictionary Use
}

\author{
Roda P. Roberts
}

\section{Introduction}

Bilingual dictionaries are obviously indispensable working tools for translators and translation trainees. And yet, there is widespread dissatisfaction with such dictionaries expressed in the literature on translation. This love-hate relationship existing between translators and bilingual dictionaries, which has been explored in some depth by Ingrid Meyer (1987, pp. 18-36), is based on the presumption that there is such a thing as an ideal general bilingual dictionary or at least an ideal general bilingual dictionary for translators. In other words, the attitude has been, and still is, that if the bilingual dictionary is not the perfect tool for translators, it is the fault of lexicographers. Thus, much attention has been focused recently on better adapting such dictionaries to meet translators' needs.

However, as the 1987 Euralex Colloquium "Translation and Lexicography" revealed, different types of translators have different needs, and it will clearly be difficult, if not impossible, to produce a general bilingual dictionary that satisfies them all. The same, in fact, can be said of all types of dictionaries, unilingual and bilingual, general and specialized. So, although we can and should justifiably expect lexicographic improvements, we should also begin to reflect more 
seriously on improving methods of dictionary use among translators and especially among translation trainees.

Although there has been much development over the last twenty years or so in the teaching of translation techniques and approaches, strategies of dictionary use have not figured prominently among them. For instance, there are no exercises for teaching appropriate dictionary use in Jean Delisle's Analyse du discours comme méthode de traduction, although there are a couple that indicate the problems that dictionaries can pose to the unwary. For example, the first exercise in this manual, intended to show the difference between equivalences at the level of linguistic meaning ("transcoded equivalents") and equivalences at the level of message meaning ("translated equivalents"), consists in having students translate isolated words and phrases using dictionaries, and then seeing how the same words and phrases may be rendered differently when they form part of a text (Delisle, 1980, pp. 131-135). While such an exercise is very useful in underlining the limitations of dictionaries, it does not show students how to deal with these limitations. Similarly, Claude Tatilon, in Traduire. Pour une pédagogie de la traduction, indicates the problems that the translation of lexical items can pose without providing any guidance on making the best use of dictionaries to solve them (1986, pp. 45-57). It is this void in translation didactics that this paper intends to fill.

\section{Importance of teaching dictionary use to translation students}

The first question that needs to be addressed is why there is this void. There is little doubt that students both in professional translation courses and in academic translation courses ${ }^{1}$ have constant recourse to dictionaries, which they use incompetently. So the need for teaching dictionary use seems obvious. And yet it has not been addressed by translation didacticians.

1. According to Delisle (1988, pp. 26-27), the purpose of a professional translation course is to teach students to manipulate language so that they can make it carry a given meaning in a given situation, while that of an academic translation course is to help students to improve their language skills. 
The reasons for this state of affairs seem to lie both in the theoretical foundations underlying current translation pedagogy and in the perceived lacks in dictionaries. Both these points are made forcefully by Delisle (1988, pp. 46-48): (a) Translation in the proper sense of the word is not transcoding. Transcoding establishes equivalences at the level of language as a system by matching words. Translation, on the other hand, establishes equivalences of utterances in context or in situation; in other words, translation equivalents arise out of the use of language in a given situation. (b) Bilingual dictionaries provide transcoded equivalents, not contextual equivalents, and are therefore improperly called "translation dictionaries". Moreover, all dictionaries, bilingual and unilingual, provide only the most common significations of words; they do not explore all the semantic possibilities of words used in context. They are thus limited in their usefulness.

However, while there is no denying that "translation is an exercise in interpretation, an intelligent analysis of the text" (Delisle, 1988, p. 48), and not just a matter of substituting one word for another, there is also little doubt that recent advances in lexicography are invalidating some of the traditional criticisms of dictionaries. Since dictionaries are increasingly corpus-based, they are not necessarily limited to the most common significations. And the corpus approach also implies that lexicography, like translation, deals with words in context, or more specifically the meaning of lexical items in texts (R.R.K. Hartmann, 1989, p. 12). This can be illustrated by taking as an example the word sympathetic, used by Delisle to illustrate the inadequacies of the transcoded equivalents and common significations generally found in bilingual dictionaries. Delisle points out, quite rightly, that the commonly cited equivalent compréhensif does not work in all contexts, and certainly not in the following excerpt from a letter by a senior civil servant: "While I am more than sympathetic to the recommendations of the social worker, we have to remember that ..." However, in addition to covering several significations of the word sympathetic, the Harrap's Standard French and English Dictionary specifically includes the phrase to be sympathetic to a proposal. This shows that today's bilingual dictionaries go well beyond the single equivalent per entry word and increasingly present words and their translation in context. In fact, modern dictionaries supply contextual information in a number of different ways: through examples (many of 
them taken from computerized corpora), context words and field labels. In addition, partial definitions, usually in the form of synonyms, are also provided to guide users in their choice of equivalents. These lexicographic trends are clearly revealed in the following (partial) entry for popular in the Collins/Robert French-English English-French Dictionary (1987):

popular ... (a) (well-liked) person, decision, book, sport populaire; (fashionable) style, model à la mode, en vogue. he is with his colleagues ses collègues l'aiment beaucoup, il jouit d'une grande popularité auprès de ses collègues; he is with the girls il a du succès or il a la cote* auprès des filles; I'm not very with the boss just now* je ne suis pas très bien vu du patron or je n'ai pas la cote auprès du patron en ce moment; (Comm) this is a very $\sim$ colour cette couleur se vend beaucoup; it is $\sim$ to despise politicians mépriser les hommes politiques est à la mode, c'est la mode de mépriser les hommes politiques.

Moreover, this entry, which is typical of good modern dictionaries, covers three out of the four possible types of lexical information that Claude Tatilon has identified as being important in translation (1986, pp. 7-12, pp. 49-53): referential information - provided by the partial definitions; pragmatic information - supplied by the style labels; and stylistic information - provided here by the field label Comm. If there is no indication of what Tatilon calls "dialectal information", it is because it is not applicable in this case. Since, as Tatilon points out, "ce qui est à traduire, c'est l'information lexicale d'un énoncé", an entry such as this provides an excellent starting point for translation students.

However, the more information is packed into dictionaries, the greater the dilemma of these students, for they are unable to find what they need in the mass of information provided. This is not surprising in light of the fact that dictionary use, like translation, is itself an exercise in interpretation. But there now exists the paradoxical situation of dictionaries, on the one hand, becoming more suitable for translation purposes, and translation students, on the other, unable to take advantage of lexicographic improvements. Instead of vainly trying to wean our students away from dictionaries or castigating them for poor 
use of dictionaries, the time has come for us, teachers of translation, to train students in the use of dictionaries - both bilingual and unilingual - for translation purposes.

\section{Strategies for improving dictionary use}

Strategies for improving dictionary use can be subdivided into four main categories on the basis of the four following objectives: (a) familiarization with different types of lexical items; (b) familiarization with different types of dictionaries; (c) familiarization with dictionary entry formats; and (d) illustration of ways to combine text analysis, translation and dictionary consultation. These four categories represent the four main problems facing translation students: knowing what to look up in a dictionary; knowing where to look for lexical information; knowing how to interpret lexical information provided; and knowing when and how to consult dictionaries during the translation process.

\subsection{Familiarization with different types of lexical items}

The reason why, in many cases, dictionary consultation gets off to a bad start is that students are often incapable of identifying complex lexical items in the source language text. This is particularly true when the source language is the student's second language. The classic example of students rendering simple soldat by simple soldier (instead of private) is a good illustration of the problem.

Students have to be made aware of the kind of bonding words can have. While they do not need to know all the degrees of bonding that may exist, they must be taught to distinguish between compounds (e.g. simple soldat above), idioms (e.g. to keep one's eyes peeled) and collocations (e.g. poser une question), for these three categories are often treated very differently in general dictionaries. Compounds are often presented as headwords in unilingual English dictionaries; compounds and idioms are sometimes grouped into separate subdivisions in entries for simple lexical items in bilingual dictionaries. Finally, collocations, when they are presented, are normally mixed in with free combinations in the examples section. Thus, students must first learn to identify these different types of lexical items before they can search for them appropriately in dictionaries. 
The best way to introduce students to types of lexical items seems to be by analyzing with them specific examples of each premarked in a text (see Appendix 1). This analysis should lead to a short theoretical presentation, accompanied by further examples. This must be followed by the scanning of a number of source texts by students, with the goal of identifying compounds, idioms and collocations therein. It seems advisable to use reasonably general texts for this purpose, since highly specialized texts have relatively few idioms. It is important to follow up each scanning exercise with a discussion, so that students who have made errors in identification can understand why. These discussions should also bring out one more general point: that the dividing line between different types of lexical items is seldom clearcut, which is why what one dictionary may classify as an idiom, another may consider a collocation. Despite this problem, however, a preliminary identification of different types of lexical items will allow for more effective dictionary consultation, for they are often treated differently in different types of dictionaries.

\subsection{Familiarization with different types of dictionaries}

The ubiquitous general bilingual dictionary, on which translation students rely so heavily, is only one of many different types of dictionaries which can and should be used in translation. The problem seems to be that very few students are aware of anything beyond the general bilingual and general unilingual dictionaries - and only one of those at that! A presentation of a variety of useful dictionary types, followed by workshop sessions in which models of different types are examined, would go a long way towards increased use of the variety of dictionaries available.

There exist a number of dictionary typologies that can be drawn on for the presentation. ${ }^{2}$ However, the instructor should limit his comments to the kinds of dictionaries most useful for translation in the

2. Among the more useful typologies are Sidney Landau's classification of dictionaries in general in Dictionaries. The Art and Craft of Lexicography (pp. 6-22), and Ali Al-Kasimi's typology of bilingual dictionaries in particular in Linguistics and Bilingual Dictionaries (pp. 17-31). 
students' working languages (which, in Canada, would generally be English and French). Given the popularity of the bilingual dictionary among translation students, it might be best to begin by introducing students to different varieties of these. Thus, a distinction should be made between the general bilingual dictionary (e.g. the Collins/Robert or the Harrap's referred to above) and specialized bilingual dictionaries (e.g. Fernand Sylvain's Dictionnaire de la comptabilite et des disciplines connexes). Another distinction that needs to be made is that between specialized dictionaries, which are limited to one field, and special purpose dictionaries, which are limited to one aspect of language such as dialect, slang, idioms or collocations (e.g. J. van Roey et al.'s Dictionnaire des faux amis anglais-français, 2001 French and English Idioms, Brueckner's French Contextuary and Dictionnaire françaisanglais de locutions et expressions verbales). Finally, it should be pointed out that not all bilingual dictionaries are bidirectional (EnglishFrench and French-English), but that many unidirectional dictionaries contain a reverse index, which points the user to the part of the dictionary where he may find the information he needs. Consideration of bilingual dictionaries should be followed by a similar examination of unilingual English and French dictionaries, which should include not only the categories discussed above but also others. For example, there are unilingual dictionaries for foreign language learners - as opposed to native speakers (e.g. Collins Cobuild English Language Dictionary) and unilingual dictionaries for younger native speakers (e.g. Dictionnaire CEC Jeunesse) which often contain clearer definitions, more information on collocations, and more examples of words in context than unilingual dictionaries intended for the general public. Translation students in Canada must also be introduced to unilingual Canadian dictionaries such as the Gage Canadian Dictionary and the Penguin Canadian Dictionary for English, and the Dictionnaire du français plus for French. Dictionaries of synonyms, which are of great help to translators, especially at the revision stage, should also be presented at this stage. A final point applicable to both bilingual and unilingual general dictionaries must be made: that pertaining to size, which is calculated in terms of the number of words covered. Students should be warned of the dangers of using any general dictionary smaller in size than a college dictionary, unless there is a special reason for doing so (e.g. consultation of a learner's dictionary for collocational 
information), and should be introduced to semi-abridged and unabridged dictionaries, which they may never have used.

Presentation and examination of these various types of dictionaries should be followed by practical exercises of various kinds. For example, students can be given a source text, with a certain number of lexical items of various kinds underlined and asked to consult two dictionaries to find the meaning of these and two dictionaries to find possible equivalents. By limiting the number of dictionaries that they may consult, the instructor forces them to choose the most pertinent ones. Thus, for instance, if the lexical item is a compound, they are more likely to find its meaning in a semi-abridged or unabridged dictionary than in a college dictionary. The results of the dictionary search should be discussed in class, so that students are made aware not only of different types of dictionaries but also of differences in quality between dictionaries of a certain type. Another exercise, which could be integrated into a normal translation assignment, could consist of having students submit an annotated translation, indicating every lexical item checked in a dictionary, along with the titles of the dictionaries consulted. (See Appendix 2, note 1 for an example.) This particular exercise would also prepare them for translation in a professional milieu, where new translators are often asked to indicate the sources of their information.

But dictionary consultation involves more than finding a dictionary that provides information on a given item. It involves above all finding pertinent information without undue waste of time. In order to be able to do this, students should be familiar with dictionary entry formats.

\subsection{Familiarization with dictionary entry formats}

Entry formats differ considerably not only from one type of dictionary to another, but also from one dictionary of a certain type to another. For example, while many bilingual specialized (field) dictionaries provide, in addition to the entry word and the target language equivalent, a definition and cross-references to quasi-synonyms and other related words, others do not. While it would be too time-consuming to examine 
jointly in class the entry formats of all the dictionaries that could be useful to the translation student, it seems important to take the time to study at least those of current general bilingual dictionaries, for many student errors can be attributed to a poor reading of information in such dictionaries. The four main English-French French-English dictionaries which translation students tend to use are the following: the Collins/Robert, M.-M. Dubois' Dictionnaire français-anglais anglaisfrançais published by Larousse (1981), the Harrap's Shorter FrenchEnglish English French Dictionary (1987), and the Harrap's New Standard referred to above. So analysis could be limited to these four. In fact, since the Harrap's Shorter is a one-volume edition of the fourvolume unabridged Harrap's New Standard, examination of two college dictionaries (the Collins/Robert and the Larousse) and one unabridged dictionary (the Harrap's New Standard) would suffice. Prior to analysis of these dictionaries, students should be required to read the introductions, which are unfortunately quite inadequate, except in the case of the Collins/Robert.

The analysis, which could be guided by a series of questions, may be based on sample dictionary entries chosen by the professor on the basis of specific lexical items identified in a source text. However, the source text as well as the lexical items examined need to be carefully chosen in order to allow students to find answers to all the questions the instructor needs to ask to focus attention on specific entry elements. These questions should cover the type of lexical items presented as subentries rather than main entries, the exhaustivity of the senses covered, the ordering of senses, the type and number of examples presented, the ordering of examples, the inclusion of collocations and idioms, the headword under which collocations and idioms are presented and their place in the entry, the way contextual information is presented, meaning discrimination devices and stylistic discrimination devices used. A series of sample questions are presented in Appendix 3. The answers could be prepared as a homework exercise and form the basis of a subsequent class discussion, or the questions could be worked on as a small-group exercise in the classroom, with each group focusing more particularly on one particular dictionary. This introductory analysis could be followed up by annotations of a certain number of lexical items in a translated text. These annotations would be more detailed than those discussed in Section 2.2. above. Not only 
would they indicate the dictionaries in which the lexical item was looked up, but they would also contain a rationale for the choice of translation, on the basis of such criteria as contextual information, meaning discrimination devices, stylistic discrimination devices and examples of usage found in dictionaries. (See Appendix 2, note 2 for an example.) These annotations would allow the instructor to ensure that students were interpreting their dictionaries correctly, if not using them efficiently.

2.4. Illustration of ways to combine text analysis, translation and dictionary consultation

Efficient dictionary use involves knowing when to consult dictionaries, which one to consult at a given stage and how to integrate dictionary information with textual information. This skill, essential for the translation student, is one that can be acquired more easily through guidance and supervised practice than through trial and error. At this point, students need to be guided through the three stages of translation - analysis of source text, translation, and revision of the translation using a concrete example, and shown how to combine dictionary consultation with each stage.

Should dictionary use be encouraged from the start of the first stage? Or does dictionary consultation at this point impede textual analysis? Lexical items in a text fall into three main categories: those that students know well and whose precise meaning is obvious in the text, those that students know vaguely and which they are tempted to look up directly in a bilingual dictionary for the purpose of translation, and those that students do not recognize. Immediate use of dictionaries to resolve problems with the latter often results in inadequate analysis of the context. This was demonstrated by an exercise done in the framework of a course on documentary research methods in the first year of a translation programme.

Students were given a number of short but complete contexts, each containing a lexical item that they knew only vaguely or that they did not know at all, with a partial translation of each passage: they were asked to translate the lexical item in question, using dictionaries if necessary, justifying the equivalent in terms of both dictionary 
information and context. The classic example of the danger of using dictionaries at too early a stage was the following sentence:

\section{J'ai passé mes vacances dans une pourvoirie.}

I went to a__ for my holidays.

Allowed the free use of dictionaries, more than $60 \%$ of the students ignored the context (the fact that pourvoirie had to be a place where one could go for a holiday), and came up with the totally nonsensical equivalents suppliers, ouffitters or ouffitting operation, on the basis of hasty dictionary consultation. The starting point for them all was a general bilingual dictionary, in which they found nothing - only Harrap's Standard contains this term and it is clearly marked "historical". Some then turned to on-line term banks, in which they found outfitters and ouffitting operation. The rest turned to unilingual French dictionaries and, finding no non-historical definition in most of them (since pourvoirie in the sense presented above is Canadian), used suppliers, which is the general equivalent provided for pourvoyeur by the Collins/Robert. Not once did they think of the inappropriateness of these equivalents in the context.

On the basis of this experience, it would seem advisable to withold dictionaries during the stage of analysis, until the students have read the text thoroughly and attempted to figure out the meaning of different lexical items in context. Students should be asked to underline those lexical items that they do not understand completely and then shown how the problems they pose can often be solved or at least delimited by a thorough study of syntactic and semotactic markers in the context and by an analysis of the situational parameters of the text. ${ }^{3}$

3. See E.A. Nida and C. Taber, The Theory and Practice of Translation (pp. 56-63) on the marking of meaning. This section also includes exercises in identifying syntactic and semotactic elements in English sentences which help to identify the specific meaning of a polysemous lexical item. See also R.P. Roberts, "Le Rôle du contexte et de la situation en traduction" (Actes du $2^{*}$ colloque sur l'enseignement fonctionnel du français et de la traduction en Amérique latine, pp. 180-192). 
Discussion following such analysis should reveal which lexical items still remain vague in the students' mind and they should be limited to looking up only these items in a suitable dictionary. At this point, a suitable dictionary would obviously be a unilingual source language (SL) dictionary, for, despite the addition of some partial definitions in a few bilingual dictionaries such as the Collins/Robert, the purpose of the latter is not to provide users with detailed indications of the meanings of SL items. Depending on the general or specialized nature of the SL items, students would be guided to a general or appropriate specialized dictionary. Their selection of the appropriate meaning and their comprehension of the definition provided could be verified by having them paraphrase the source text (ST) sentence containing the difficult lexical item and seeing whether that paraphrase made sense within the text.

Once the analysis of the ST is completed, the actual work of translation begins. Here again, students should be encouraged not to turn blindly to dictionaries for answers. They should be reminded of Peter Newmark's adage that for non-standardized language there is rarely only one correct equivalent, although for standardized language there often is only one (1981, p. 16). Among the lexical items they feel they cannot render, they should be helped to make a distinction between standardized terms, collocations and idioms and non-standardized lexical items. They should then be allowed to consult appropriate bilingual dictionaries only for the former at this point. They should then be required to reexpress the lexical information contained in the rest of the text without having a target language (TL) equivalent at their fingertips. Only when they have attempted such a paraphrastic translation and when the resultant text has been discussed should they be allowed to use their bilingual dictionaries to find a more concise and perhaps stylistically more appropriate way of rendering certain lexical items. Having already worked through a paraphrastic translation, they should be better able to judge whether a dictionary-proposed equivalent does fit into the overall context, not only of the ST but also of the target text (TT).

At the third stage of revision, students should be asked to put away their bilingual dictionaries and work only with unilingual TL dictionaries of various kinds. It is at this point that they will verify in 
a general unilingual dictionary the precise meaning of TL equivalents provided by the bilingual dictionary which they are unsure about. It is also at this point that they may turn to collocational dictionaries or learner's dictionaries to ensure, for instance, that they have used the usual verb with a given noun. This is when they will turn to dictionaries of synonyms in an attempt to vary the vocabulary used or to find the most exact synonym to render a nuance or a register. A final reading of the TT will be followed by a check of the TT against the ST to ensure that improvements in the vocabulary of the TT have not led to any omissions, additions or distortions of the ST.

This first in-class translation exercise, intended to show appropriate dictionary consultation during the entire translation process, can be followed up occasionally by spot checks of dictionary use during specific stages. For instance, students could be asked to undertake at home the analysis of an ST intended for a sight translation exercise in class and to look up the meanings of only a given number of terms identified in advance. Their contextual analysis of other lexical items should then be quickly verified before the start of sight translation. Another exercise, intended to oblige students both to limit their dictionary use and to use their dictionaries efficiently, is that of sight translation practised more or less as in interpreter training programmes. Students are handed an ST which they have not seen before, given a short period of time to read it, analyze it, and find any necessary equivalents, and then asked to translate the text aloud into a tape recording machine. Translation students, in contrast to interpretation students, may be given more preparation time and allowed to use any dictionaries they like during this period. However, given the limited period of preparation, they will soon learn to use dictionaries only when strictly essential. They will thus better learn the role of dictionary consultation in the translation process.

\section{Analysis of some basic special purpose dictionaries useful to English/French translators}

While introducing students to a large variety of dictionaries, the professor will no doubt orient them towards those he finds the most useful. Presented below is a schematic analysis of some special purpose dictionaries that I recommend more particularly. 


\subsection{Learners' Dictionaries}

As indicated in 2.2. above, learners' dictionaries, while limited in vocabulary, provide clearer semantic information and more detailed syntactic information than general unilingual dictionaries for native users. They are therefore particularly useful for translators.

\subsubsection{Collins Cobuild English Language Dictionary. (London, Collins, 1988.)}

This is a learner's dictionary of English, which is nevertheless of use also to native English speakers. It is undoubtedly the best English learner's dictionary on the market.

\section{Special features}

- Simple explanation of meanings, with the word being explained normally included in the explanation in such a way that you can see how it is typically used in English (e.g. barbarity: 1. Barbarity is extremely cruel behaviour... 2. A barbarity is an extremely cruel and shocking act. Cf. Random House Webster's: barbarity: 1 brutal or inhuman conduct; cruelty; 2 . an act or instance of cruelty.)

- Each new usage of the headword clearly separated. (e.g. compare includes 6 subdivisions dealing with the following usages: 1 . to compare two or more things, 2. to compare someone or something to someone or something else, 3. something compares favourably or unfavourably with something else, 4. something is large, small, etc. compared to or with something else, 5 . something does not compare with something else, and 6. something is beyond compare. Cf. Random House Webster's which makes 9 subdivisions, but on the basis of senses that are sometimes hard to understand from the definitions provided; e.g. "to appear in quality, progress, etc., as specified".)

- Inclusion of many collocations (e.g. under anchor are found the verb+noun collocations drop anchor, cast anchor, and weigh anchor. Cf. Random House Webster's, which does not include any of these collocations). 
- Systematic inclusion of examples taken from actual modern usage. (e.g. anchor, in the abstract sense of "mainstay", is illustrated by two examples in the Collins Cobuild - the anchor of marriage; your material body is the anchor of consciousness - while Random House Webster's has none at all.

- Structural information in a separate column, not found in any general use unilingual dictionary (e.g. ampère: count noun, usually after numeral).

Use

- For Anglophones: verification of collocations and of usage.

- For Francophones: explanation of meanings, awareness of collocations, and appropriate insertion of words in sentences.

3.1.2. Robert méthodique. Ed. J. Rey-Debove. Paris, Le Robert, 1988.

There is no real equivalent of the Collins Cobuild in French. The closest is the Robert methodique, which is more geared towards those learning French as a mother tongue than second language learners. However, it does have certain features that make it specially interesting for translation students.

\section{Special features}

- Simpler definitions than in most general purpose unilingual dictionaries (e.g. débat 1. action de débattre une question; cf. Petit Robert 1: action de débattre une question, de la discuter).

- Simple, non-literary examples, which often include many common collocations (e.g. under débat, in the sense of "action de débattre une question" are found not only éclaircir un débat and entrer dans le coeur du débat - which are also included in the Petit Robert 1 - but also ouvrir, ranimer, trancher le débat).

- Inclusion of antonyms in a given sense division, immediately after the definition and synonyms, rather than at the end of the entry (e.g. débile: 
1. qui manque de force physique. V. Déficient, faible, frêle [...] Contr. Vigoureux. Cf. Petit Robert 1 débile: 1.... 2....3..... Ant. fort, vigoureux).

- Additional remarks which cover special difficulties and exceptions related to the headword, not normally found in general purpose unilingual dictionaries (e.g. effronté: se dit surtout des enfants et des jeunes personnes).

Use

- For Anglophones: simple explanation of meanings, awareness of collocations and of particular difficulties related to the headword.

- For Francophones: verification of collocations and of usage.

\subsection{Dictionaries of Collocations}

"Proper words in proper places make the true definition of style," according to Jonathan Swift (1720). Certainly, the use of appropriate word combinations shows awareness of the idiomatic nature of language. Moreover, the fact that collocations do not necessarily coincide from one language to another make the use of collocation dictionaries essential for translators.

3.2.1. The BBI Combinatory Dictionary of English. Eds. M. Benson et al. Amsterdam/Philadelphia, John Benjamins, 1986.

This dictionary presents a large variety of both lexical and grammatical collocations for a series of headwords (primarily nouns, adjectives and verbs). Since its purpose is solely to present collocations, it contains far more such combinations than even unabridged English dictionaries such as the Webster's Third.

\section{Special features}

- Collocations presented in their most obvious form (e.g. to detonate a bomb), and not as part of examples (e.g. They detonated the bomb and destroyed the bridge in Longman Dictionary of Contemporary English) or as part of the definition of the entry word (e.g. detonate: to 
cause (a bomb, mine, etc.) to explode - in the Collins English Dictionary).

- Clear separation of different types of collocations within a given entry (e.g. bomb: 1. to detonate, explode, set off; drop; fuse a $\sim$ [verb+noun collocations);....10. a explodes, goes off [noun+verb collocations]).

- A number of synonymous collocations provided (cf. bomb above).

- Indication of meanings of polysemous entry words to enable users to choose the appropriate collocation for a given meaning (e.g.body ['substance'] ['firmness'] 1. to give $\sim$ to ['group'] ['unit'] 2. an advisory; deliberative; elected; governing; study $\sim$...)

- Examples provided to illustrate usage of certain collocations (e.g. body... 3 . in $\mathrm{a} \sim$ (they presented their petition in $\mathrm{a} \sim$ ).

- Inclusion of some phrases transitional between collocations and idioms (e.g. bird: as free as a bird) and of important fixed phrases (e.g. business: to mix business with pleasure), which are often neglected by dictionaries of idioms.

Use

- For Anglophones: verification of collocations when writing in or translating into English.

- For Francophones: awareness of idiomatic word combinations in English.

3.2.2. Les Mots et les idées. Dictionnaire des termes cadrant avec les idees. Ed. U. Lacroix. Paris, Fernand Nathan, 1956.

This dictionary, dated as it is, is still really the only dictionary of collocations in French. It consists of noun headwords followed by the main verbs, adjectives and nouns used in combination with them. 
- Grouping together of different collocational types (e.g. blessure: Causer, provoquer, panser, envenimer une blessure. Couvrir, cribler de blessures. Une blessure se ferme, fait souffrir, se rouvre. - QUAL.: profonde, grave, dangereuse [...] blesser grièvement, légèrement, gravement, affreusement, cruellement.)

- Cross-references to synonymous headwords with similar collocations. (e.g. billet: Voir argent, lettre)

Use

- For Anglophones: awareness of idiomatic word combinations in French.

- For Francophones: verification of collocations when writing in or translating into French.

\subsection{Dictionaries of neologisms}

New words and new senses are constantly added to the existing vocabulary. Since many of them prove to have only a short life span, traditional dictionaries tend to ignore such items until they become more established. However, translators do not enjoy the luxury of waiting for neologisms to become established, for the latter often find their way into texts. Thus, they need to be aware of dictionaries of neologisms to which they can turn when they come up with a blank in their usual general unilingual dictionaries.

3.3.1. The Longman Register of New Words. Volume Two 1990. Ed. John Ayto. Harlow, England, Longman, 1990.

This dictionary, although published in England, covers lexical items culled from newspapers and journals from many areas of the Englishspeaking world, including the US and Canada. It is therefore international in scope. 
- Simple definitions provided ((e.g. contra noun someone, especially from the right wing, who opposed another).

- Authentic examples (often more than one per lexical item) provided to show sense and usage. (e.g. contra: Tory contras opposed to Heseltine can no longer refer to him without revulsion. To call him 'a tart' as the Daily Mail did on Friday shows how close to panic they are.)

- Notes on usage (e.g. abortuary noun, American derogatory)

- Entries also on evolution of grammatical and syntactic uses of existing words (e.g. accused noun [...] A subtle but significant change is taking place in the grammar of the noun accused. Hitherto it has been used only with the definite article the, but now there are signs that it is turning into an ordinary countable noun, capable of being preceded by an indefinite article).

Use

- For Anglophones: awareness of new meanings and new words in English; awareness of changes in English usage.

- For Francophones: awareness of new meanings and new words in English.

3.3.2. Dictionnaire des mots contemporains. Ed. Pierre Gilbert. Paris, Le Robert, 1980.

This dictionary completes and expands on information found in the Petit Robert.

\section{Special features}

- Simple definitions provided (e.g. abandonnique adj. Qui éprouve une crainte maladive d'être abandonné) 
- Authentic examples (often more than one per lexical item) provided to show sense and usage. (e.g. abandonnique adj. Le caractère un peu difficile de cet enfant risque de lasser très vite des parents nourriciers. Il en changera sans cesse, il deviendra "abandonnique", comme disent les psychiatres).

- Usage notes (e.g. aéroglisseur: Rem. 2: Ce terme tend à remplacer l'anglicisme hovercraft; il s'emploie concurremment avec naviplane).

- Cross-references to other related articles (e.g. cross-references to aéroglisseur and hovercraft in the entry for naviplane).

\section{Conclusion}

What dictionaries to use, how to get the most out of dictionaries and how to use dictionaries efficiently in the translation process are all, in my opinion, integral components of translation pedagogy. But where and when should these components be covered? In most professional translation programmes, which often include not only translation courses but also a documentation course, it is generally taken for granted that dictionary use will be integrated into the latter. While this is possible at least in the case of two of the objectives presented above (familiarization with different types of dictionaries and with dictionary entry formats), this solution is often unsatisfactory. Since such a course is sometimes given by a documentalist or librarian rather than a translator, the practical connection between the actual translation process and dictionary use may not be adequately made. In any case, there are still many professional translation programmes that do not have a distinct documentation course and academic translation courses are rarely, if ever, complemented by such a course. Thus, it seems logical to include dictionary use exercises into the first translation course offered.

In order not to delay introduction of translation per se in a translation course, it might be a good idea to begin with the fourth objective, that of illustrating ways in which to combine text analysis, translation and dictionary consultation. Working through the translation of a text in class, with controlled consultation of a limited number of dictionaries proposed by the instructor, will allow the latter to present 
simultaneously the various stages of the translation process and the role of dictionaries in the process, while at the same time introducing students to some basic dictionaries and helping them to decipher essential information therein. This can be followed by more specific work on each of the four objectives, either in the form of exercises complementary to translation, or in the form of annotations to translations.

Whatever form it takes, improvement of dictionary use is a must for students learning translation. For, as all translation teachers will acknowledge, students have neither the knowledge nor the willpower to stay away from dictionaries completely. Nor is complete abstention from dictionary use desirable, for it is only by using lexicographic tools that students can expand their lexical knowledge to the point where they need to consult dictionaries less. What is essential therefore is not to avoid the issue of dictionary use either in the name of theoretical principles or in the hope that it will be dealt with elsewhere by someone else, but to make dictionary use an integral component of translation pedagogy.

University of Ottawa

\section{References}

\section{Theoretical Works and Translation Manuals}

AL-KASIMI, A.M. (1977). Linguistics and Bilingual Dictionaries. Leiden, E.J. Brill.

DELISLE, J. (1980). L'Analyse du discours comme méthode de traduction. Ottawa, University of Ottawa Press.

(1988). Translation: an Interpretive Approach. Ottawa, University of Ottawa Press.

HARTMANN, R.R.K. (1989). "Lexicography, Translation and the Socalled Language Barrier." Translation and Lexicography. Ed. 
M. Snell-Hornby and E. Pöhl. Kirksville, Missouri, NMSU, pp. 9-20.

LANDAU, S.I. (1984). Dictionaries. The Art and Craft of Lexicography. New York, Charles Scribner's Sons.

MEYER, I. (1987). "Towards a New Type of Bilingual Dictionary". Ph.D. dissertation, University of Montreal.

NEWMARK, P. (1981). Approaches to Translation. Oxford, Pergamon Press.

NIDA, E.A. and C. TABER (1974). The Theory and Practice of Translation. Leiden, E.J. Brill.

ROBERTS, R.P. (1982). "Le rôle du contexte et de la situation en traduction." Actes du $2^{*}$ colloque sur l'enseignement fonctionnel du français et de la traduction en Amérique latine. Buenos Aires, I.N.S.P., pp. 180-192.

TATILON, C. (1986). Traduire. Pour une pédagogie de la traduction. Toronto, Éditions du GREF.

\section{Dictionaries}

Brueckner's French Contextuary. Ed. J.H. Brueckner et al. Englewood, NJ, Prentice-Hall, 1975.

The BBI Combinatory Dictionary of English. Eds. M. Benson et al. Amsterdam/Philadelphia, John Benjamins, 1986.

Collins and Robert French-English English-French Dictionary. Ed. B. Atkins et al. London/Paris, Collins/Le Robert, 1987.

Collins Cobuild English Language Dictionary. London, Collins, 1988.

Collins Dictionary of the English Language. Ed. P. Hanks. London \& Glasgow, Collins, 1986. 
Dictionnaire CEC Jeunesse, Ed. J.-C. Boulanger et al. Montréal, CEC, 1986.

Dictionnaire de la comptabilité et des domaines connexes. Ed. F. Sylvain et al. Montréal, Institut canadien des comptables agréés, 1982.

Dictionnaire des expressions et locutions figurées. Ed. A. Rey et al. Paris, Le Robert, 1979.

Dictionnaire des faux amis anglais-français. Ed. J. van Roey et al. Paris, Duculot, 1988.

Dictionnaire des mots contemporains. Ed. Pierre Gilbert. Paris, Le Robert, 1980.

Dictionnaire du français plus. Ed. C. Poirier et al. Montreal, CEC, 1988.

Dictionnaire français-anglais anglais-français. Ed. M.-M. Dubois et al. Paris, Larousse, 1981.

Dictionnaire français-anglais de locutions et expressions verbales. Ed. M. Dubois et al. Paris, Larousse, 1973.

Dictionnaire thématique visuel. Ed. J.C. Corbeil. Montréal, QuébecAmérique, 1987.

Gage Canadian Dictionary. Ed. W.S. Avis et al. Toronto, Gage, 1983.

Harrap's Shorter French-English English-French Dictionary. P. Collin et al. London, Harrap, 1982.

Harrap's Standard French and English Dictionary, 4 vols. Ed. J.E. Mansion et al. London, Harrap, 1972 \& 1980.

Longman Dictionary of Contemporary English. Harlow, England, Longman, 1987. 
Lexis. Dictionnaire de la langue française. Ed. J. Dubois et al. Paris, Larousse, 1987.

The Longman Register of New Words. Volume Two 1990. Ed. John Ayto. Harlow, England, Longman, 1990.

Les Mots et les idées. Dictionnaire des termes cadrant avec les idees. Ed. U. Lacroix. Paris, Fernand Nathan, 1956.

Penguin Canadian Dictionary. Ed. T. Paikeday. Markham/Missisauga, Penguin/Copp Clark Pitman, 1990.

Petit Larousse illustré. Paris, Larousse, 1990.

Petit Robert 1. Ed. A. Rey et al. Paris, Le Robert, 1987.

Petit Robert 2. Ed. P. Robert. Paris, Le Robert, 1987 .

Random House Dictionary of the English Language. S. Berg Flexner et al. New York, Random House, 1987.

Random House Webster's College Dictionary. New York, Random House, 1991.

Robert méthodique. Ed. J. Rey-Debove. Paris, Le Robert, 1988.

Webster's Third New International Dictionary of the English Language. Boston, Merriam-Webster, 1986.

2001 French and English Idioms. Ed. F. Denœu. New York, Barron's. 1982. 


\section{Appendix 1}

Identification of different types of lexical items in a text

Petite capitale ayant donné son nom à un territoire où la France tiendrait à l'aise au moins trois fois, Québec étendit un jour son autorité sur près des trois quarts du continent nord-américain. Fondée en 1608 par le Saintongeais Samuel de Champlain sur une étroite bande de terre au pied du cap Diamant, elle prit bientôt d'assaut son rocher pour se répandre sur le plateau où, dès le début, les communautés religieuses construisirent leurs monastères, leurs couvents, leurs collèges.

J. Archambault, Le Québec tel quel

(Québec, Éditeur officiel du Québec, 1975, p. 65)

à l'aise: idiomatic expression

étendre l'autorité sur: collocation

bande de terre: compound

prendre d'assaut: idiomatic expression

communauté religieuse: compound

\section{Appendix 2}

Annotated Source Text and Translation

Source text

Petite capitale ayant donné son nom à un territoire où la France tiendrait à l'aise au moins trois fois, Québec étendit un jour son autorité sur près des trois quarts du continent nord-américain. Fondée en 1608 par le Saintongeais Samuel de Champlain sur une étroite bande de terre au pied du cap Diamant, elle prit bientôt d'assaut(1) son rocher pour se répandre sur le plateau où, dès le début, les communautés religieuses construisirent leurs monastères, leurs couvents, leurs collèges.

Le Québec tel quel, p. 65 


\section{Translation}

Québec City, a small capital which gave its name to a territory into which France could easily fit three times over, once extended its authority over almost three-fourths of the North American continent. Founded in 1608 by Samuel de Champlain, a native of Saintonge, on a narrow strip of land at the foot of Cap Diamant, it soon took over the cliff and spread onto the plateau, where, fromthe beginning, religious orders built their monasteries, convents and colleges.

\section{Note 1: prendre d'assaut}

- Meaning checked in Lexis. Expression found (with difficulty) only in one example under prendre. No separate definition. Meaning also checked in Dictionnaire des expressions et locutions figurées. Expression under assaut with following definitions: "entrer de force dans (un lieu)" and "prendre de haute lutte".

- Possible equivalents checked in Collins/Robert. Found expression under assaut with equivalents "to take by storm, to assault". There were also examples of more figurative uses, but none were close to context and therefore their translations were considered non-pertinent. Possible equivalents also checked in 2001 French and English Idioms. Expression not found under assaut or prendre.

Note 2: Equivalent "assault" (see note 1 above) does not seem figurative enough. Equivalent "take by storm" researched for suitability. Webster's 3rd provides definition of by storm (under storm), but example with take by storm ("take an audience by storm") does not correspond to ST context. Collins Cobuild provides two definitions, each with an example, for take by storm but neither fits ST context. Therefore translation provided paraphrases idea of "domination" found in prendre d'assaut. 


\section{Appendix 3}

Sample questions intended to draw attention to dictionary formats

Questions based on the source text found in Appendix 1. Answers in brackets following questions.

1.1 Is Saintongeais found in the Petit Robert 1? (Yes, but only in an appendix.)

1.2 Why do you think it is not a regular entry in this dictionary? (Because it is a proper noun and language dictionaries do not include many proper names as regular entries.)

1.3 In what kind of dictionary are you likely to find proper nouns as main entries? (A dictionary of proper nouns such as Petit Robert 2 or an encyclopedic dictionary such as the Petit Larousse.)

2.1 Is bande de terre found in the Petit Robert 1 and in Lexis?

(bande de terrain found in $P R 1$, but nothing in Lexis.)

2.2 Is communauté religieuse found in the Petit Robert 1 and in Lexis? (Yes, in PR1. In Lexis, found only congrégation religieuse.)

2.3 Where you did find these compounds, were they listed as separate entries? (No; bande de terrain found under bande in $P R 1$; communauté religieuse found under religieux in $P R 1$; congrégation religieuse found under religion in Lexis.)

2.4 Where were these compounds listed in these entries? (In the pertinent meaning division, along with other examples of usage.)

2.5 Is a definition provided for these compounds? (No, just for the element under which the compound is listed.)

3.1 Why is congrégation religieuse found under religion and not under religieux in Lexis? (There is no full entry for religieux - just a cross-reference to religion.)

3.2 Is there a full entry for the noun rocher in Lexis? (No, just a cross-reference to the entry for roche.) 
3.3 What can be deduced from the answers to the two preceding questions? (Lexis groups together words that are semantically and morphologically related.)

4.1 Is bande de terre found in the Collins/Robert, Larousse, and Harrap's Standard? (Yes; under bande and terre in $C / R$ and under bande in Larousse. Not in Harrap's.)

4.2 Is communaute religieuse found in the Collins/Robert, Larousse, and Harrap's Standard? (Only in Harrap's under religieux.)

4.3 Where were the compounds that were found listed in the entry? (In the pertinent meaning division, along with other examples of usage, except in the Collins/Robert entry for bande, where bande de terre was listed in a separate section which covered several compounds beginning with bande) 